\title{
IDENTIFIKASI KARAKTER KEWIRAUSAHAAN MAHASISWA STKIP PGRI SIDOARJO
}

\section{THE IDENTIFICATION OF STUDENTS' ENTREPRENEURSHIP CHARACTER AT STKIP PGRI SIDOARJO}

\author{
Tri Achmad Budi Susilo
}

STKIP PGRI Sidoarjo, Email: trisusilostkip@gmail.com

\begin{abstract}
ABSTRAK
STKIP PGRI Sidoarjo adalah lembaga pendidik dan tenaga kependidikan (LPTK) yang mana desain kurikulum dirancang untuk mencetak mahasiswa menjadi tenaga pendidik. Mata kuliah kewirausahaan di STKIP PGRI Sidoarjo adalah mata kuliah yang wajib ditempuh mahasiswa dengan capaian pembelajaran agar mahasiswa mendapatkan pengetahuan dan keterampilan dalam menjalankan kewirausahaan. Tujuan penelitian ini untuk mengidentifikasi karakter Kewirausahaan mahasiswa prodi PGSD dan prodi pendidikan Sejarah STKIP PGRI Sidoarjo. Jenis penelitian yang digunakan adalah kuantitatif sedangkan instrumen yang digunakan adalah test angket. Populasi yang digunakan adalah mahasiswa prodi PGSD dan pendidikan Sejarah yang sedang mengikuti kuliah kewirausahaan. Sampel yang digunakan adalah 56 mahasiswa. Hasil penelitian menunjukkan 22 atau 39,3\% mahasiswa memiliki karakter kewirausahaan yang tinggi, 28 atau 50\% mahasiswa memiliki karakter kewirausahaan sedang dan 6 atau 10,7\% mahasiswa memiliki karakter kewirausahaan rendah. Hal ini menunjukkan, meskipun mahasiswa menempuh studi di lembaga pendidik dan tenaga kependidikan, lembaga pencetak profesi guru ternyata memiliki minat yang tinggi untuk menjadi seorang wirausahawan.
\end{abstract}

Kata kunci: Kewirausahaan, Karakter Kewirausahaan.

\begin{abstract}
STKIP PGRI Sidoarjo is an educational institution and teaching staff in which curriculum design is designed to print students into educators. Entrepreneurship courses at STKIP PGRI Sidoarjo are subjects that must be taken by students with learning outcomes so that students gain knowledge and skills in running entrepreneurship. The purpose of this study was to identify the entrepreneurship character of PGSD study program students and Historical education study program STKIP PGRI Sidoarjo. This type of research is quantitative while the instrument used is a questionnaire test. The population used is PGSD study program students and History education who are currently attending entrepreneurship courses. The sample used was 56 students. The results showed 22
\end{abstract}


or $39.3 \%$ of students had a high entrepreneurial character, 28 or $50 \%$ of students had a moderate entrepreneurial character and 6 or 10.7\% of students had a low entrepreneurial character. This shows that, even though, students study at educational institutions and teaching staff, the professional teacher printing institute turns out to have a high interest in becoming an entrepreneur.

Keywords: Entrepreneurship, Entrepreneurship Character

\section{Pendahuluan}

\section{A. Pengertian Kewirausahaan.}

\begin{abstract}
Kewirausahaan (Entrepreneurship)
adalah proses mengidentifikasi, mengembangkan, dan membawa visi ke dalam kehidupan. Visi tersebut bisa berupa ide inovatif, peluang, cara yang lebih baik dalam menjalankan sesuatu. Hasil akhir dari proses tersebut adalah penciptaan usaha baru yang dibentuk pada kondisi risiko atau ketidakpastian.
\end{abstract}

Sejalan dengan perkembangan dan tantangan seperti adanya krisis ekonomi, pemahaman kewirausahaan baik melalui pendidikan formal maupun pelatihanpelatihan di segala lapisan masyarakat kewirausahaan menjadi berkembang.Orang yang melakukan kegiatan kewirausahaan disebut wirausahawan.Muncul pertanyaan mengapa seorang wirausahawan (entrepreneur) mempunyai cara berpikir yang berbeda dari manusia pada umumnya. Mereka mempunyai motivasi, panggilan jiwa, persepsi dan emosi yang sangat terkait

dengan nilai nilai, sikap dan perilaku sebagai manusia unggul.

Menurut Robbin \& Coulter (2009) Kewirausahaan adalah proses di mana seorang individu atau kelompok individu menggunakan upaya terorganisir dan sarana untuk mencari peluang untuk menciptakan nilai dan tumbuh dengan memenuhi keinginan dan kebutuhan mereka melalui inovasi dan keunikan, tidak peduli sumber daya apa pun yang saat ini dikendalikan.

Menurut Soeharto Prawiro (1997), kewirausahaan adalah nilai yang dibutuhkan untuk memulai bisnis (fase start-up) dan pengembangan bisnis (venture growth).

\begin{tabular}{llrr}
\multicolumn{1}{c}{ Menurut } & Acmad & Sanusi (1994) \\
kewirausahaan & adalah & nilai & yang \\
dimanifestasikan dalam perilaku yang & das \\
merupakan dasar & sumber & daya, kekuatan \\
pendorong, tujuan, strategi, kiat, proses, dan \\
hasil bisnis.
\end{tabular}
Menurut Acmad Sanusi (1994)

(n)




\section{B. Karakteristik Kewirausahaan.}

Menjadi seorang entrepreneur haruslah memiliki karakter yang kuat agar nanti pada saat menjalani kegiatan kewirausahaannya dapat mengambil keputusan yang cepat dan tepat dan tidak mudah untuk dipengaruhi opini-opini yang tidak jelas.

Karakteristik sikap yang wajib dimiliki oleh seorang wirausahaan adalah sebagai berikut :

\section{Motif Berprestasi Tinggi}

Para ahli mengemukakan bahwa seseorang memiliki minat berwirausaha karena adanya motif tertentu, yaitu motif berprestasi (achievement motive). Menurut Suryana, (2003:32) Motif berprestasi ialah suatu nilai sosial yang menekankan pada hasrat untuk mencapai yang terbaik guna mencapai kepuasan secara pribadi. Faktor dasarnya adalah kebutuhan yang harus dipenuhi.

Kebutuhan berprestasi wirausaha terlihat dalam bentuk tindakan untuk melakukan sesuatu yang lebih baik dan lebih efisien dibandingkan sebelumnya. Wirausaha yang memiliki motif berprestasi pada umumnya memiliki ciri-ciri sebagai berikut:

a) Ingin mengatasi sendiri kesulitan dan persoalan-persoalan yang timbul pada dirinya b) Selalu memerlukan umpan balik yang segera untuk melihat keberhasilan dan kegagalan.

c) Memiliki tanggung jawab personal yang tinggi.

d) Berani menghadapi resiko dengan penuh perhitungan.

e) Menyukai tantangan dan melihat tantangan secara seimbang (fiftyfifty). Jika tugas yang diembannya sangat ringan, maka wirausaha merasa kurang tantangan, tetapi ia selalu menghindari tantangan yang paling sulit yang memungkinkan pencapaian keberhasilan sangat rendah.

\section{Selalu Perspektif}

Seorang wirausahawan hendaknya seorang yang mampu menatap masa dengan dengan lebih optimis. Melihat ke depan dengan berfikir dan berusaha. Usaha memanfaatkan peluang dengan penuh perhitungan. Orang yang berorientasi ke masa depan adalah orang yang memiliki persepktif dan pandangan kemasa depan. Karena memiliki pandangan jauh ke masa depan maka ia akan selalu berusaha untuk berkarsa dan berkarya (Suryana, 2003:23).

Kuncinya pada kemampuan untuk menciptakan sesuatu yang baru serta berbeda dengan yang sudah ada. Walaupun dengan 
risiko yang mungkin dapat terjadi, seorang yang perspektif harus tetap tabah dalam mencari peluang tantangan demi pembaharuan masa depan. Pandangan yang jauh ke depan membuat wirausaha tidak cepat puas dengan karsa dan karya yang sudah ada. Karena itu ia harus mempersiapkannya dengan mencari suatu peluang.

\section{Memiliki Kreatifitas Tinggi}

Menurut Teodore Levit (dalam Suryana, 2003), kreativitas adalah kemampuan untuk berfikir yang baru dan berbeda. Menurut Levit, kreativitas adalah berfikir sesuatu yang baru (thinking new thing), oleh karena itu menurutnya kewirausahaan adalah berfikir dan bertindak sesuatu yang baru atau berfikir sesuatu yang lama dengan cara-cara baru.

Menurut Zimmerer dalam buku yang ditulis Suryana (2003:24) dengan judul buku "Entrepreneurship And The New Venture Formation", mengungkapkan bahwa ide-ide kreativitas sering muncul ketika wirausaha melihat sesuatu yang lama dan berfikir sesuatu yang baru dan berbeda.

Oleh karena itu kreativitas adalah menciptakan sesuatu dari yang asalnya tidak ada (generating something from nothing). Inovasi adalah kemampuan untuk menerapkan kreativitas dalam rangka memecahkan persolan-persolan dan peluang untuk meningkatkan dan memperkaya kehidupan. Dari definisi diatas, kreativitas mengandung pengertian, yaitu:

a) Kreativitas adalah menciptakan sesuatu yang asalnya tidak ada.

b) Hasil kerjasama masa kini untuk memperbaiki masa lalu dengan cara baru.

c) Menggantikan sesuatu dengan sesuatu yang lebih sederhana dan lebih baik.

\section{Memiliki Perilaku Inovatif Tinggi}

Menjadi wirausaha yang handal tidaklah mudah. Tetapi tidaklah sesulit yang dibayangkan banyak orang, karena setiap orang dalam belajar berwirausaha.

Menurut Poppy King (2005), wirausaha muda dari Australia yang terjun ke bisnis sejak berusia 18 tahun, ada tiga hal yang selalu dihadapi seorang wirausaha di bidang apapun, yakni: pertama, obstacle (hambatan); kedua, hardship (kesulitan); ketiga, very rewarding life (imbalan atau hasil bagi kehidupan yang memukau).

5. Selalu Komitmen dalam Pekerjaan, Memiliki Etos Kerja dan Tanggung Jawab

Seorang wirausaha harus memiliki jiwa komitmen dalam usahanya dan tekad yang bulat didalam mencurahkan semua perhatianya pada usaha yang akan 
digelutinya, didalam menjalankan usaha tersebut seorang wirausaha yang sukses terus memiliki tekad yang mengebu-gebu dan menyala-nyala (semangat tinggi) dalam mengembangkan usahanya, ia tidak setengah-setengah dalam berusaha, berani menanggung resiko, bekerja keras, dan tidak takut menghadapi peluang-peluang yang ada dipasar. Tanpa usaha yang sungguh-sunguh terhadap pekerjaan yang digelutinya maka wirausaha sehebat apapun pasti menemui jalan kegagalan dalam usahanya. Oleh karena itu penting sekali bagi seorang wirausaha untuk komit terhadap usaha dan pekerjaannya.

\section{Mandiri atau Tidak Ketergantuangan}

Sesuai dengan inti dari jiwa kewirausahaan yaitu kemampuan untuk menciptakan seuatu yang baru dan berbeda (create new and different) melaui berpikir kreatif dan bertindak inovatif untuk menciptakan peluang dalam menghadapi tantangan hidup, maka seorang wirausaha harus mempunyai kemampuan kreatif didalam mengembangkangkan ide dan pikiranya terutama didalam menciptakan peluang usaha didalam dirinya, dia dapat mandiri menjalankan usaha yang digelutinya tanpa harus bergantung pada orang lain, seorang wirausaha harus dituntut untuk selalu menciptakan hal yang baru dengan jalan mengkombinasikan sumber-sumber yang ada disekitarnya, mengembangkan teknologi baru, menemukan pengetahuan baru, menemukan cara baru untuk menghasilkan barang dan jasa yang baru yang lebih efisien, memperbaiki produk dan jasa yang sudah ada, dan menemukan cara baru untuk memberikan kepuasan kepada konsumen.

\section{Berani Menghadapi Risiko}

Richard Cantillon, orang pertama yang menggunakan istilah entrepreneur di awal abad ke-18, mengatakan bahwa wirausaha adalah seseorang yang menanggung risiko. Wirausaha dalam mengambil tindakan hendaknya tidak didasari oleh spekulasi, melainkan perhitungan yang matang. Ia berani mengambil risiko terhadap pekerjaannya karena sudah diperhitungkan.

Oleh sebab itu, wirausaha selalu berani mengambil risiko yang moderat, artinya risiko yang diambil tidak terlalu tinggi dan tidak terlalu rendah. Keberanian menghadapi risiko yang didukung komitmen yang kuat, mendorong wirausaha untuk terus berjuang mencari peluang sampai memperoleh hasil. Hasil-hasil itu harus nyata/jelas dan objektif, dan merupakan umpan balik (feedback) bagi kelancaran kegiatannya (Suryana, 2003:14$15)$.

8. Selalu Mencari Peluang 
Esensi kewirausahaan yaitu tanggapan yang positif terhadap peluang untuk memperoleh keuntungan untuk diri sendiri dan atau pelayanan yang lebih baik pada pelanggan dan masyarakat, cara yang etis dan produktif untuk mencapai tujuan, serta sikap mental untuk merealisasikan tanggapan yang positif tersebut. Pengertian itu juga menampung wirausaha yang pengusaha, yang mengejar keuntungan secara etis serta wirausaha yang bukan pengusaha, termasuk yang mengelola organisasi nirlaba yang bertujuan untuk memberikan pelayanan yang lebih baik bagi pelanggan/masyarakat.

\section{Memiliki Jiwa Kepemimpinan}

Seorang wirausaha yang berhasil selalu memiliki sifat kepemimpinan, kepeloporan dan keteladanan. Ia selalu ingin tampil berbeda, lebih dahulu, lebih menonjol. Dengan menggunakan kemampuan kreativitas dan inovasi, ia selalu menampilkan barang dan jasa-jasa yang dihasilkanya lebih cepat, lebih dahulu dan segera berada dipasar. Ia selalu menampilkan produk dan jasa-jasa baru dan berbeda sehingga ia menjadi pelopor yang baik dalam proses produksi maupun prmasaran.

10. Memiliki Keterampilan Personal

Wirausahawan Andal.

Wirausahawan andal memiliki ciri-ciri dan cara-cara sebagai berikut: a) Percaya diri dan mandiri yang tinggi untuk mencaripenghasilan dan keuntungan melalui usaha yang dilaksanakannya.

b) Mau dan mampu mencari dan menangkap peluang yang menguntungkan dan memanfaatkan peluang tersebut.

c) Mau dan mampu bekerja keras dan tekun untuk menghasilkan barang dan jasa yang lebih tepat dan effisien.

d) Mau dan mampu berkomunikasi, tawar menawar dan musyawarah dengan berbagai pihak, terutama kepada pembeli.

e) Menghadapi hidup dan menangani usaha dengan terencana, jujur, hemat, dan disiplin.

f) Mencintai kegiatan usahanya dan perusahaannya secara lugas dan tangguh tetapi cukup luwes dalam melindunginnya.

g) Mau dan mampu meningkatkan kapasitas diri sendiri dan kapasitas perusahaan dengan memanfaatkan dan memotivasi orang lain (leadership/ managerialship) serta melakukan perluasan dan pengembangan usaha dgn resiko yang moderat. 
h) Berusaha mengenal dan mengendalikan lingkungan serta menggalang kerja sama yang saling menguntungkan dengan berbagai pihak yang berkepentingan dengan perusahaan.

\section{Metode Penelitian}

Jenis penelitian ini adalah kuantitatif dengan tujuan untuk mengetahui tingkat karakter kewirausahaan mahasiswa STKIP PGRI Sidoarjo, yang sedang menempuh mata kuliah kewirausahaan. Instrumen penelitian adalah kuesioner dengan indikator-indikator sebagai berikut: motivasi, kapasitas, menjalin jejaring dan kemitraan, serta dukungan (Center for Rural Entrepreneurship). Angket disebar pada mahasiswa prodi PGSD dan prodi pendidikan Sejarah melalui google form dan mahasiswa diberi waktu 7 hari untuk mengisi dan mengembalikan kuesioner sejak angket dikirimkan. Kuesioner yang telah diisi dan dikirimkan kembali, diolah dan diberi nilai/skor dengan menggunakan skala likert. Adapun katagori nilai/skor tingkat karakter kewirausahaan mahasiswa adalah sebagai berikut: karakter kewirausahaan mahasiswa rendah (skor $1 \mathrm{sd}$ 4), karakter kewirausahaan mahasiswa sedang (skor 5 sd 7 ) dan karakter kewirausahaan mahasiswa tinggi (skor 8 sd $10)$.

\section{Data dan Analisis Data}

Populasi penelitian ini adalah mahasiswa kelas pagi prodi PGSD, mahasiswa kelas sore prodi PGSD dan mahasiswa kelas sore prodi pendidikan Sejarah. Sampel yang digunakan adalah 56 mahasiswa, yang terdiri dari 24 mahasiswa kelas pagi prodi PGSD dan 18 mahasiswa kelas sore prodi PGSD, serta 14 mahasiswa kelas sore prodi Pendidikan Sejarah, Mahasiswa kelas pagi sebagian besar adalah mahasiswa murni yang menempuh kuliah dan tidak sedang bekerja, sedangkan mahasiswa kelas sore sebagian besar adalah mahasiswa yang kuliah sambil bekerja. Hasil penelitian menunjukkan mahasiswa yang memiliki tingkat karakter kewirausahaan tinggi sebesar 22 atau 39,3 $\%$, tingkat karakter kewirausahaan sedang sebesar 28 atau 50\%, dan tingkat karakter kewirausahaan rendah sebesar 6 atau 10,7\%, Mahasiswa kelas pagi merupakan mahasiswa murni yang menempuh kuliah dan tidak sedang bekerja, sedangkan mahasiswa kelas sore merupakan mahasiswa yang sedang menempuh kuliah sambil bekerja pada pagi hari. Selanjutnya dapat juga disimpulkan bahwa meskipun mahasiswa menempuh studi di lembaga pendidik dan tenaga 
kependidikan, lembaga pencetak profesi guru ternyata memiliki minat yang tinggi untuk menjadi seorang wirausahawan.

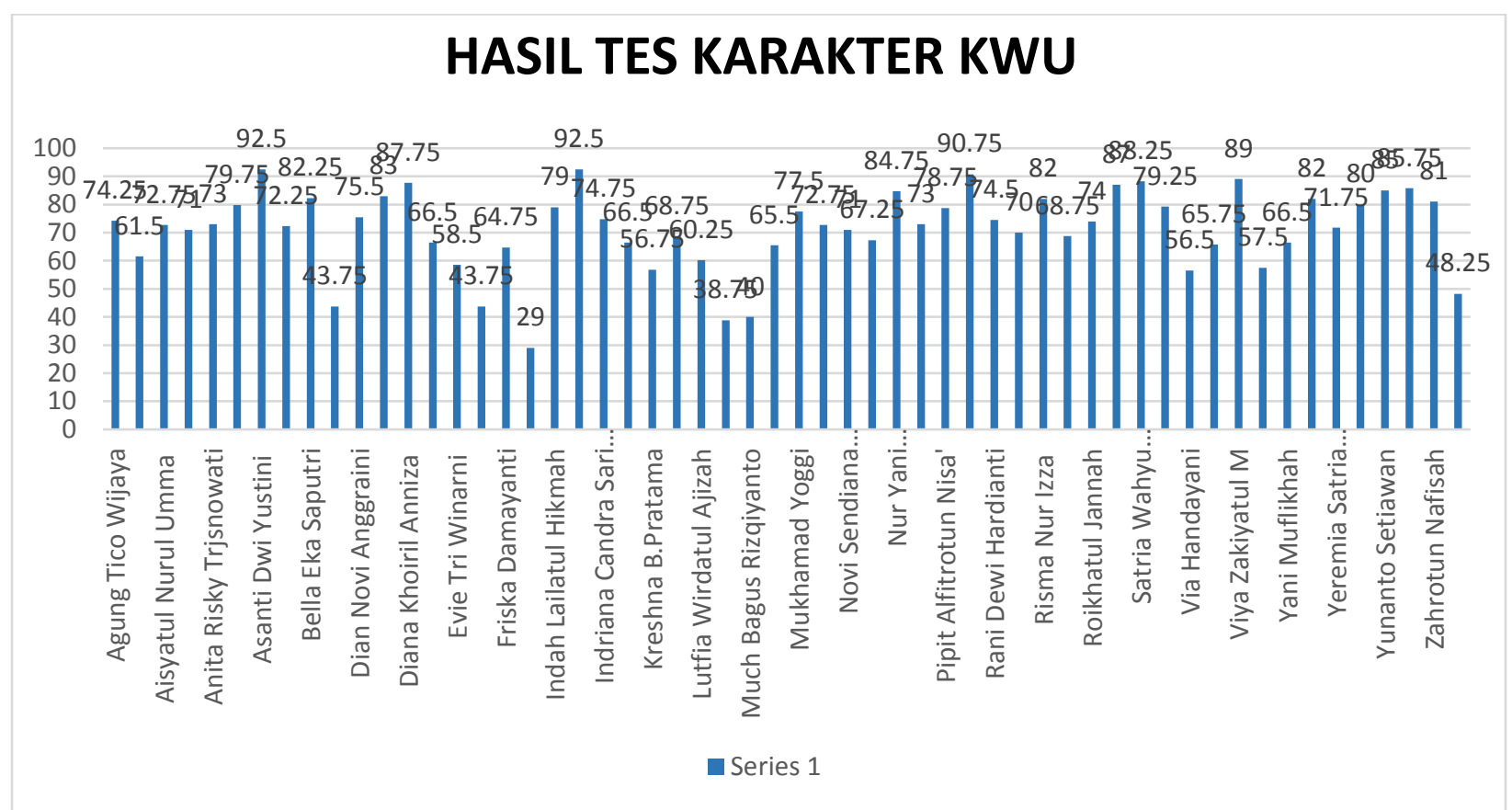

\section{Simpulan}

Mahasiswa prodi PGSD dan Pendidikan Sejarah STKIP PGRI Sidoarjo memiliki tingkat karakter kewirausahaan tinggi sebesar 22 atau 39,3 \%, tingkat karakter kewirausahaan sedang sebesar 28 atau 50\%, dan tingkat karakter kewirausahaan rendah sebesar 6 atau 10,7 \%. Hal tersebut menunjukkan meskipun mahasiswa menempuh studi di lembaga pendidik dan tenaga kependidikan, lembaga pencetak profesi guru ternyata memiliki minat yang tinggi untuk menjadi seorang wirausahawan.

\section{Daftar Pustaka}

Ir. Hendro, M.M. 2011. Dasar-Dasar Kewirausahaan, Erlangga; Jakarta

Kasali Rhenald. 2010. Modul Kewirausahaan. Jakarta Selatan: PT Mizan Publika

Erni. 2012. Proses Kewirausahaan, (Online), (http://www.ernirismayana.blogspot.c om). 27 Desember 2011

Robbins, Stephen P and Mary Coulter (2009).

Manajemen. Pearson. United State America. Edisi Kedelapan Jilid 2

Soeharto Prawiro. 1997. Kewirausahaan, Bandung. CV. Alfabeta. 
Sanusi, Ahmad. 1994. Menelaah Potensi

Perguruan Tinggi untuk Membina Program Kewirausahaan dan Mengantar Pewirausaha Muda, Makalah Seminar. Kopma IKIP.

Suryana. 2003. Kewirausahan: Pedoman praktis, kiat dan proses menuju sukses (Edisi Revisi). Jakarta: Salemba Empat. 